\title{
Enhancement of Ceramics Based Red-Clay by Bulk and Nano Metal Oxides for Photon Shielding Features
}

\author{
Mohamed Elsafi ${ }^{1, *(\mathbb{D}}$, Mirvat Fawzi Dib ${ }^{1}$, Hoda Ezzelddin Mustafa ${ }^{2}$, M. I. Sayyed ${ }^{3,4} \mathbb{D}^{\text {, }}$ \\ Mayeen Uddin Khandaker ${ }^{5}$ (D), Abdullah Alsubaie ${ }^{6}$, Abdulraheem S. A. Almalki ${ }^{7}$, Mahmoud I. Abbas ${ }^{1}$ (D) \\ and Ahmed M. El-Khatib ${ }^{1}$
}

\section{check for} updates

Citation: Elsafi, M.; Dib, M.F.; Mustafa, H.E.; Sayyed, M.I.; Khandaker, M.U.; Alsubaie, A.; Almalki, A.S.A.; Abbas, M.I.; El-Khatib, A.M. Enhancement of Ceramics Based Red-Clay by Bulk and Nano Metal Oxides for Photon Shielding Features. Materials 2021, 14, 7878. https://doi.org/10.3390/ ma14247878

Academic Editor: Chao Xu

Received: 14 November 2021 Accepted: 9 December 2021 Published: 19 December 2021

Publisher's Note: MDPI stays neutral with regard to jurisdictional claims in published maps and institutional affiliations.

Copyright: (C) 2021 by the authors. Licensee MDPI, Basel, Switzerland. This article is an open access article distributed under the terms and conditions of the Creative Commons Attribution (CC BY) license (https:/ / creativecommons.org/licenses/by/ $4.0 /)$.
1 Physics Department, Faculty of Science, Alexandria University, Alexandria 21511, Egypt; mirvatdib2018@gmail.com (M.F.D.); mabbas@physicist.net (M.I.A.); elkhatib60@yahoo.com (A.M.E.-K.)

2 Khalifa Medical Center, Abu-Dhabi 60843, United Arab Emirates; hezzeddin68m@gmail.com

3 Department of Physics, Faculty of Science, Isra University, Amman 11622, Jordan; dr.mabualssayed@gmail.com

4 Department of Nuclear Medicine Research, Institute for Research and Medical Consultations (IRMC), Imam Abdulrahman bin Faisal University, P.O. Box 1982, Dammam 31441, Saudi Arabia

5 Center for Applied Physics and Radiation Technologies, School of Engineering and Technology, Sunway University, Bandar Sunway 47500, Selangor, Malaysia; mayeenk@sunway.edu.my

6 Department of Physics, College of Khurma, Taif University, P.O. Box 11099, Taif 21944, Saudi Arabia; a.alsubaie@tu.edu.sa

7 Department of Chemistry, Faculty of Science, Taif University, Taif 21974, Saudi Arabia; almalki.a@tu.edu.sa

* Correspondence: mohamedelsafi68@gmail.com; Tel.: +201-273-895-292

\begin{abstract}
We prepared red clays by introducing different percentages of $\mathrm{PbO}, \mathrm{Bi}_{2} \mathrm{O}_{3}$, and $\mathrm{CdO}$. In order to understand how the introduction of these oxides into red clay influences its attenuation ability, the mass attenuation coefficient of the clays was experimentally measured in a lab using an HPGe detector. The theoretical shielding capability of the material present was obtained using XCOM to verify the accuracy of the experimental results. We found that the experimental and theoretical values agree to a very high degree of precision. The effective atomic number $\left(Z_{\text {eff }}\right)$ of pure red clay, and red clay with the three metal oxides was determined. The pure red clay had the lowest $Z_{\text {eff }}$ of the tested samples, which means that introducing any of these three oxides into the clay will greatly enhance its $Z_{\text {eff, }}$, and consequently its attenuation capability. Additionally, the $Z_{\text {eff }}$ for red clay with $10 \mathrm{wt} \% \mathrm{CdO}$ is lower than the $\mathrm{Z}_{\text {eff }}$ of red clay with $10 \mathrm{wt} \% \mathrm{Bi}_{2} \mathrm{O}_{3}$ and $\mathrm{PbO}$. We also prepared red clay using $10 \mathrm{wt} \% \mathrm{CdO}$ nanoparticles and compared its attenuation ability with the red clay prepared with $10 \mathrm{wt} \% \mathrm{PbO}, \mathrm{Bi}_{2} \mathrm{O}_{3}$, and $\mathrm{CdO}$ microparticles. We found that the MAC of the red clay with $10 \mathrm{wt} \%$ nano-CdO was higher than the MAC of the clay with microparticle samples. Accordingly, nanoparticles could be a useful way to enhance the shielding ability of current radiation shielding materials.
\end{abstract}

Keywords: red clay; bulk metal oxides; nano-CdO; MAC; $\mathrm{Z}_{\text {eff }}$

\section{Introduction}

Most countries around the world consider nuclear technology to be an alternative energy source to solve the problem of nonrenewable energy, which will run out one day. Due to the increased use of radioisotopes and radiation-emitting devices in various medical and industrial fields, it is necessary to study the ability of some readily available materials for use in construction, such as concrete, rocks and clay, to protect against gamma rays [1-4].

It is well known that materials with a high atomic number and density are very useful as ionizing radiation shields. The most common materials used for these purposes are lead, alloys, glasses, composites, some types of concrete, and clay materials [5-8].

Clay has been used since antiquity, in Mesopotamia, Egypt, Africa, and the Middle East; and more recently in Roman and Islamic civilizations in Asia, North America, Me- 
dieval Europe, and so on. Civilizations have built entire cities out of clay materials. Clay products are now used by more than a third of the world's population due to their high quality and resistance to weathering. Clay material in architecture is a part of the heritage of almost every nation on every continent.

In many developed and developing countries, clay materials are used for building and construction. Clay products, such as ceramic pots, fired bricks, and tiles (for ceilings and floors) are less expensive and more durable than cement, and they are environmentally friendly and safe building materials that are widely available at low prices in various regions [9-11]. Furthermore, clay has refractory properties such as a high melting point, thermochemical stability, abrasion resistance, and thermal shock resistance. One of the most important characteristics that distinguishes clay and from other materials is that it is non-toxic. Due to these characteristics, clay materials are suitable for use as shielding materials (designing radiation shields from clay materials) [12-14].

With the emergence of nanotechnology as a progressive branch of science in recent years, various types of nanoparticles have been used to design radiation shields. The advantage of using nanomaterials in this field is that the distances between molecules are very small, increasing the possibility of photon collisions with atoms of the material, and thus improving the material's ability to attenuate photons [15-18].

Nuclear engineers have placed a high value on nanocomposites containing metals or oxides of heavy elements, and their research has focused on developing these nanocomposites for use as an alternative to traditional radiation shields due to their promising properties, such as their lightweight, and desirable mechanical, chemical, and physical properties $[19,20]$. The majority of previous research has focused on developing some types of clay mixed with some heavy oxides for use as radiation shields, but very few studies have focused on developing clays mixed with nano-scale particles of heavy oxides [21].

Some types of Egyptian clay, which are natural building materials that may be considered for use as a radiation-shielding materials, will be investigated in this study. Clay can be found in relatively large reserves northeast of the city of Aswan in Egypt. Many companies produce it for the local ceramics and tile industries, mainly in Wadi Abu Sabira and Wadi Abu Ajaj. Due to the industrial importance of Aswan clay, some technical studies have been conducted to investigate its physical properties, either in its raw state as used for the manufacture of ceramics and tiles, or as a mixture with other raw materials [22].

Red clay is a clean and environmentally friendly building material that can be used as a radiation shield in radiation protection applications, or it can be added to concrete mixtures in certain proportions as an alternative to sand, resulting in an increase in its density, which leads to an increase in gamma ray attenuation. This form of clay's high melting point is indicative of its potential thermal stability in the case of prolonged exposure to high-energy radiation, and its compressive strength is appropriate for the production of high-strength shielding materials [23].

However, to the best of the authors' knowledge, studies related to the radio protective properties of these clays are almost non-existent, which prompted the researchers in this work to study the radio protective properties of red clay found in the Aswan region of Egypt, after adding a group of heavy-metal oxides as both micro- and nano-scale particles. In this work, some red clay originating from ceramic samples was prepared and the chemical composition was deduced by EDX analysis. The attenuation parameters of these samples were experimentally determined and compared with theoretical values produced by the XCOM software. The effective atomic number (Zeff) was calculated for a broad energy range.

\section{Materials and Methods}

First, the red clay samples were collected from Aswan city, Egypt, then dried, crushed, and sieved using a sieve with a hole diameter of $100 \mu \mathrm{m}$. Secondly, micro-scale metal oxides $\left(\mathrm{PbO}, \mathrm{Bi}_{2} \mathrm{O}_{3}\right.$ and $\left.\mathrm{CdO}\right)$ were purchased from the El-Gomhouria Company in Egypt. The average particle size of these oxides ranged from 50 to $100 \mu \mathrm{m}$, and their purity was up 
to $99 \%$. Meanwhile, nano-scale cadmium oxide (CdO) particles (average size $40 \mathrm{~nm}$ ) were purchased from the NanoTech Company in Egypt, where they were chemically prepared. The red clay was mixed with the proportions of oxides shown in Table 1, and blended well by a mixer to obtain a homogeneous mixture. This mixture of powders was added to a proportion of water (mixture: water $=3: 1$ ) to form the compound, then put in a plastic container and allowed to dry for two weeks. Thus, 10 samples were prepared.

Table 1. Chemical composition and densities of prepared ceramic-based red clay samples.

\begin{tabular}{|c|c|c|c|c|c|c|c|c|c|c|}
\hline \multirow{2}{*}{ Sample } & \multirow{2}{*}{$\begin{array}{c}\text { Weight } \\
\text { Percentage } \\
(\%)\end{array}$} & \multirow{2}{*}{$\begin{array}{l}\text { Density } \\
\left(\mathrm{g} \cdot \mathrm{cm}^{-3}\right)\end{array}$} & \multicolumn{8}{|c|}{ Weight Fraction of Elements (\%) } \\
\hline & & & Al & $\mathbf{O}$ & Si & Ti & $\mathrm{Fe}$ & $\mathbf{P b}$ & Bi & Cd \\
\hline Red clay (R.C) & 100 & $1.982 \pm 0.005$ & 18,036 & 49,132 & 27,238 & 1.186 & 4.407 & - & - & - \\
\hline $\mathrm{R} . \mathrm{C}+\mathrm{PbO}$ & $90: 10$ & $2.151 \pm 0.003$ & 16,232 & 44,932 & 24,512 & 1.067 & 3.964 & 9.283 & - & - \\
\hline $\mathrm{R} . \mathrm{C}+\mathrm{PbO}$ & $70: 30$ & $2.602 \pm 0.018$ & 12,628 & 36,547 & 19,067 & 0.833 & 3.085 & 27.849 & - & - \\
\hline R.C $+\mathrm{Bi}_{2} \mathrm{O}_{3}$ & $90: 10$ & $2.150 \pm 0.012$ & 16,232 & 45,245 & $24 ., 512$ & 1.068 & 3.964 & - & 8.970 & - \\
\hline R.C $+\mathrm{Bi}_{2} \mathrm{O}_{3}$ & $70: 30$ & $2.147 \pm 0.005$ & 12,627 & 37,487 & 19,068 & 0.833 & 3.086 & & 26.910 & \\
\hline R.C + CdO & $90: 10$ & $2.562 \pm 0.008$ & 16,232 & 45,460 & 24,512 & 1.066 & 3.964 & - & - & 8.754 \\
\hline R.C + CdO NPs & $90: 10$ & $2.152 \pm 0.017$ & 16,320 & 45,372 & 24,475 & 1.054 & 3.976 & - & - & 8.791 \\
\hline R.C + CdO & $70: 30$ & $2.565 \pm 0.004$ & 12,628 & 38,134 & 19,067 & 0.833 & 3.086 & - & - & 26,262 \\
\hline R.C + CdO NPs & $70: 30$ & $2.599 \pm 0.020$ & 12,522 & 38,152 & 19,004 & 0.835 & 3.087 & - & - & 26,398 \\
\hline $\mathrm{R} \cdot \mathrm{C}+\mathrm{PbO}+\mathrm{Bi}_{2} \mathrm{O}_{3}+\mathrm{CdO}$ & 70:10:10:10 & $2.581 \pm 0.011$ & 12,628 & 37,389 & 19,067 & 0.833 & 3.086 & 9.283 & 8.969 & 8.754 \\
\hline
\end{tabular}

These samples were left for two weeks to dry, and a sample of each type was then taken to measure its chemical composition by energy dispersive X-ray (EDX) analysis, as shown in Table 1. From knowledge of their compositions, the MAC could be theoretically calculated using the WinXCom program [24-26]. The radiation shielding parameters were experimentally determined by the narrow-beam method. A high-purity germanium (HPGe) detector was used, alongside point sources of different energies in cases where their activities and other specifications could be found (Table 2) [27-33]. The sample was placed between the source and the detector using a collimator and lead shield. The schematic diagram of the experimental measurement technique is shown in Figure 1. Measurements were undertaken for a time sufficient for the statistical uncertainty of the area under the peak to be less than $1 \%$, and the count rate was calculated in the presence and absence of the sample. The MAC is calculated according to the following equation [34-36]:

$$
\mathrm{MAC}=\frac{1}{x \cdot \rho} \ln \frac{A}{A_{O}}
$$

where $A$ and $A_{0}$ represent the areas under the peak, and the count rates obtained from the spectrum in the presence and absence of the absorbing sample, respectively, $\times(\mathrm{cm})$ represents the thickness of the measured clay sample, and $\rho\left(\mathrm{g} / \mathrm{cm}^{3}\right)$ the density. The linear attenuation coefficient or LAC is defined as the probability of photons interacting with matter per unit path length, and was calculated to determine other important shielding parameters (such as HVL and TVL) where the LAC equals MAC $\rho$. The HVL and TVL represent the thicknesses needed to attenuate $50 \%$ and $90 \%$ of the initial photon intensity, respectively, and can be evaluated by the following equations $[37,38]$ :

$$
\mathrm{HVL}=\frac{\ln 2}{\mathrm{LAC}}, \mathrm{TVL}=\frac{\ln 10}{\mathrm{LAC}}
$$

Table 2. The activities and other specifications for point sources that are used in this study.

\begin{tabular}{cccccc}
\hline $\begin{array}{c}\text { PTB } \\
\text { Nuclide }\end{array}$ & Energy (keV) & $\begin{array}{c}\text { Emission } \\
\text { Probability }\end{array}$ & $\begin{array}{c}\text { Initial Activity } \\
\mathbf{( k B q )}\end{array}$ & $\begin{array}{c}\text { Reference } \\
\text { Date }\end{array}$ & $\begin{array}{c}\text { Uncertainty } \\
(\mathbf{k B q})\end{array}$ \\
\hline Am-241 & 59.52 & 35.9 & 259 & & \pm 2.6 \\
Ba-133 & 80.99 & 34.1 & 275.3 & 1 January & \pm 2.8 \\
Cs-137 & 356.21 & 21.4 & 385 & 2009 & \pm 4.0 \\
Co-60 & 1173.23 & 34.1 & 99.9 & & \pm 1.5 \\
\hline
\end{tabular}




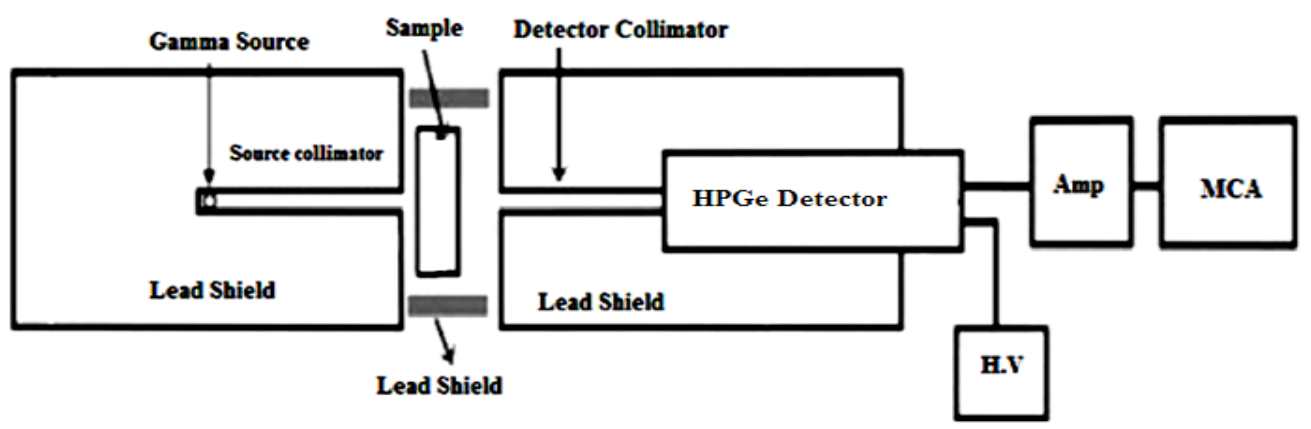

Figure 1. The schematic diagram of the experimental setup for the narrow-beam method.

The effective atomic number $\left(Z_{\text {eff }}\right)$ is another useful radiation interaction factor that is used to describe the attenuating properties of mixtures or compounds in terms of the elements present, and depends on the incoming photon energy. $Z_{\text {eff }}$ values for the studied polymers can be obtained using Equation (3) [39]:

$$
Z_{e f f}=\frac{\sum_{i} f_{i} A_{i}(\mathrm{MAC})_{i}}{\sum_{j} \frac{A_{j}}{Z_{j}}(\mathrm{MAC})_{j}}
$$

where $f_{i}, A i$, and $Z_{i}$ refer to the mole fraction, atomic weight, and an atomic number of each constituent element in the selected polymer, respectively.

\section{Results and Discussion}

Figure 2 shows the mass attenuation coefficient (MAC) for the tested clays with different micro-samples as a function of energy between 0.015 and $15 \mathrm{MeV}$. The values were calculated using the XCOM software. In this work, red clay, which is used as a building material, was prepared using three oxides: $\mathrm{PbO}, \mathrm{CdO}$, and $\mathrm{Bi}_{2} \mathrm{O}_{3}$. In Figure 2, $10 \mathrm{wt} \%$ $\mathrm{PbO}, \mathrm{CdO}$, and $\mathrm{Bi}_{2} \mathrm{O}_{3}$ was added to the red clay, and the figure presents the effect of this addition on MAC. In the low-energy region (energies less than $70 \mathrm{MeV}$ ), it can be seen that the red clay with $10 \mathrm{wt} \% \mathrm{CdO}$ has a greater MAC than the red clay with $\mathrm{PbO}$ and $\mathrm{Bi}_{2} \mathrm{O}_{3}$. This difference is due to the k-absorption edges of $\mathrm{Cd}, \mathrm{Pb}$, and $\mathrm{Bi}$, which occur at $26.71,88$, and $90.53 \mathrm{keV}$, respectively. Due to Cd's k-absorption edge, it has a high attenuation ability, near 20-30 keV, causing it to have a higher MAC value than $\mathrm{PbO}$ and Bi2O3. Meanwhile, as the energy approaches $80 \mathrm{keV}$, the k-absorption edges of $\mathrm{Pb}$ and $\mathrm{Bi}$ cause the clays with these two elements to have a higher MAC than the clay with $\mathrm{CdO}$.

In order to understand the influence of introducing $\mathrm{PbO}_{2} \mathrm{Bi}_{2} \mathrm{O}_{3}$, and $\mathrm{CdO}$ into red clay on its attenuation ability, the MAC and LAC of the clays were experimentally measured in a lab, and from these experimental values the HVL, TVL, and MFP ewere determined. Before analyzing the shielding ability of the clays, it is important to verify the accuracy of the experimental results, as all the conclusions rely on it. For this, the theoretical shielding capability of a material is obtained using XCOM, and then these results are compared with the experimental data. The theoretical results of red clay (no additives), red clay with $10 \mathrm{wt} \% \mathrm{PbO}$, red clay with $10 \mathrm{wt} \% \mathrm{Bi}_{2} \mathrm{O}_{3}$, and red clay with $10 \mathrm{wt} \% \mathrm{CdO}$ were compared at four different energies, as shown in Figure 3. All four tested parameters (MAC, 1AC, HVL, and MFP) had a good level of agreement between their experimental and theoretical results, at all energies, and for all tested samples. For instance, the difference between the experimental and theoretical MAC for red clay with $10 \mathrm{wt} \% \mathrm{CdO}$ at $0.0596 \mathrm{MeV}$ is negligible, meaning that the two values agree to a very high degree of precision. The same results were found for the other samples and the other tested parameters. This result proves that the experimental setup used in this study can be reliably used to determine the shielding ability of the investigated clays. 


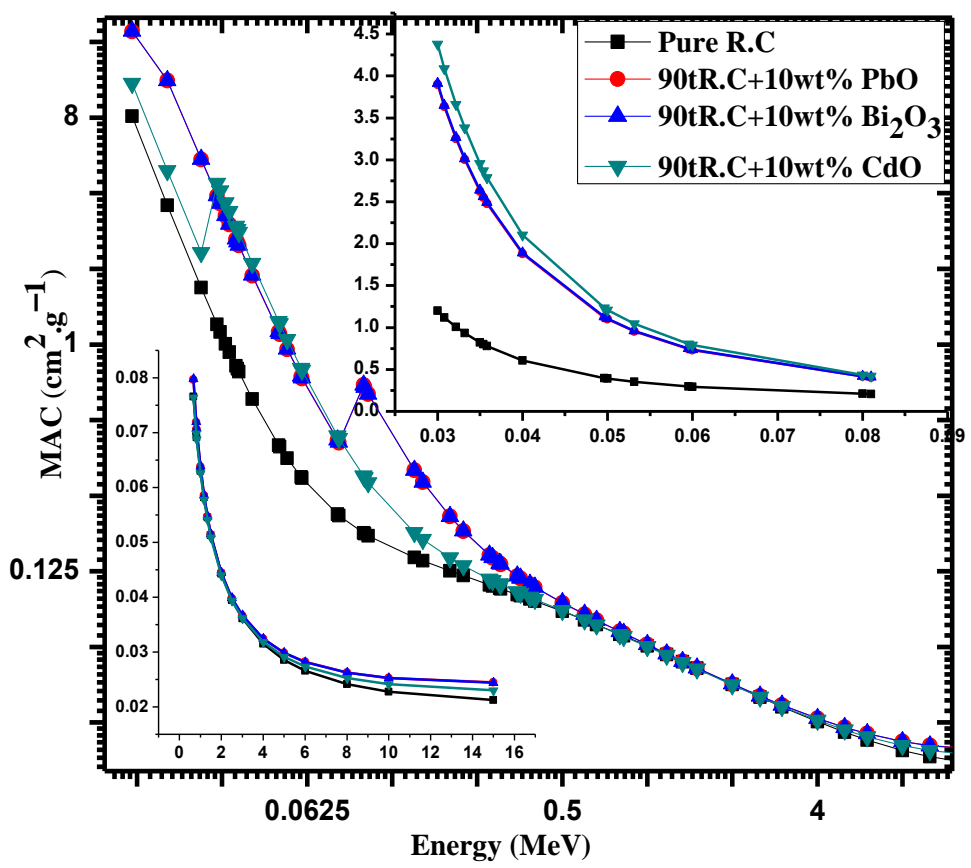

Figure 2. The MAC as a function of energy ranging from $0.015-15 \mathrm{MeV}$ for different micro-samples calculated by XCOM software.
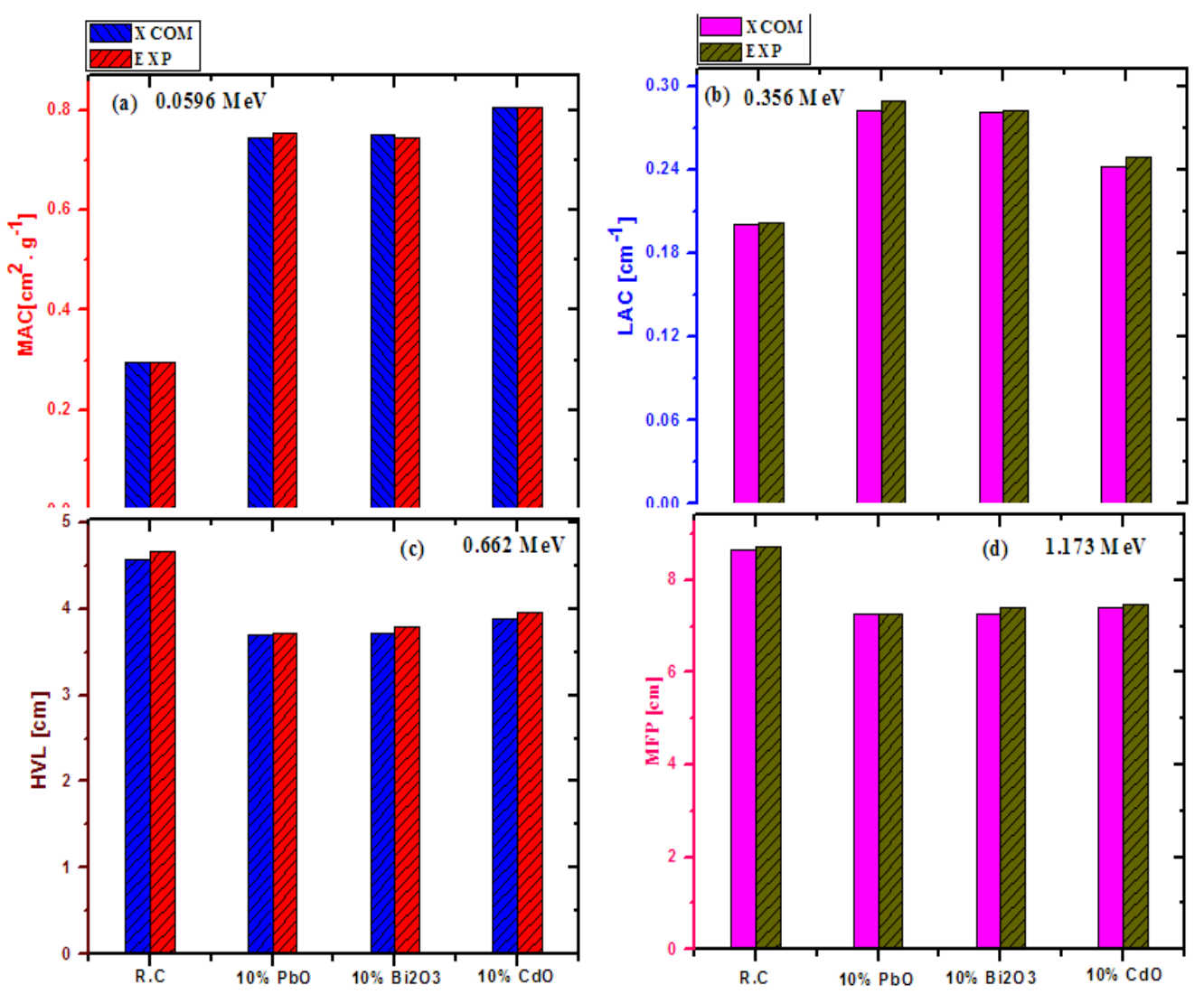

Figure 3. The difference between the experimental and XCOM results of (a) MAC at $0.0596 \mathrm{MeV}$, (b) LAC at $0.356 \mathrm{MeV}$, (c) HVL at $0.662 \mathrm{MeV}$ and (d) MFP at $1.173 \mathrm{MeV}$ for red clay, as well as different $10 \%$ wt doped oxide-clays.

Figure 4 shows the difference between the experimental and simulated XCOM results of four different parameters at four selected energies. To ensure the validity of the 
experimental results, the accuracy of the obtained values was determined for the red clay samples with $30 \mathrm{wt} \% \mathrm{PbO}, \mathrm{Bi}_{2} \mathrm{O}_{3}$ and $\mathrm{CdO}$ instead of $10 \mathrm{wt} \%$, to test whether increasing the amount of additives affected the reliability of the results. This figure has similar trends to the previous figure; namely, the difference between the XCOM and the experimental results was extremely small (within an acceptable experimental error). This once again proves that the experimental setup used in this work provides accurate data for red clay with both low and high amounts of $\mathrm{PbO}, \mathrm{Bi}_{2} \mathrm{O}_{3}$, and $\mathrm{CdO}$.
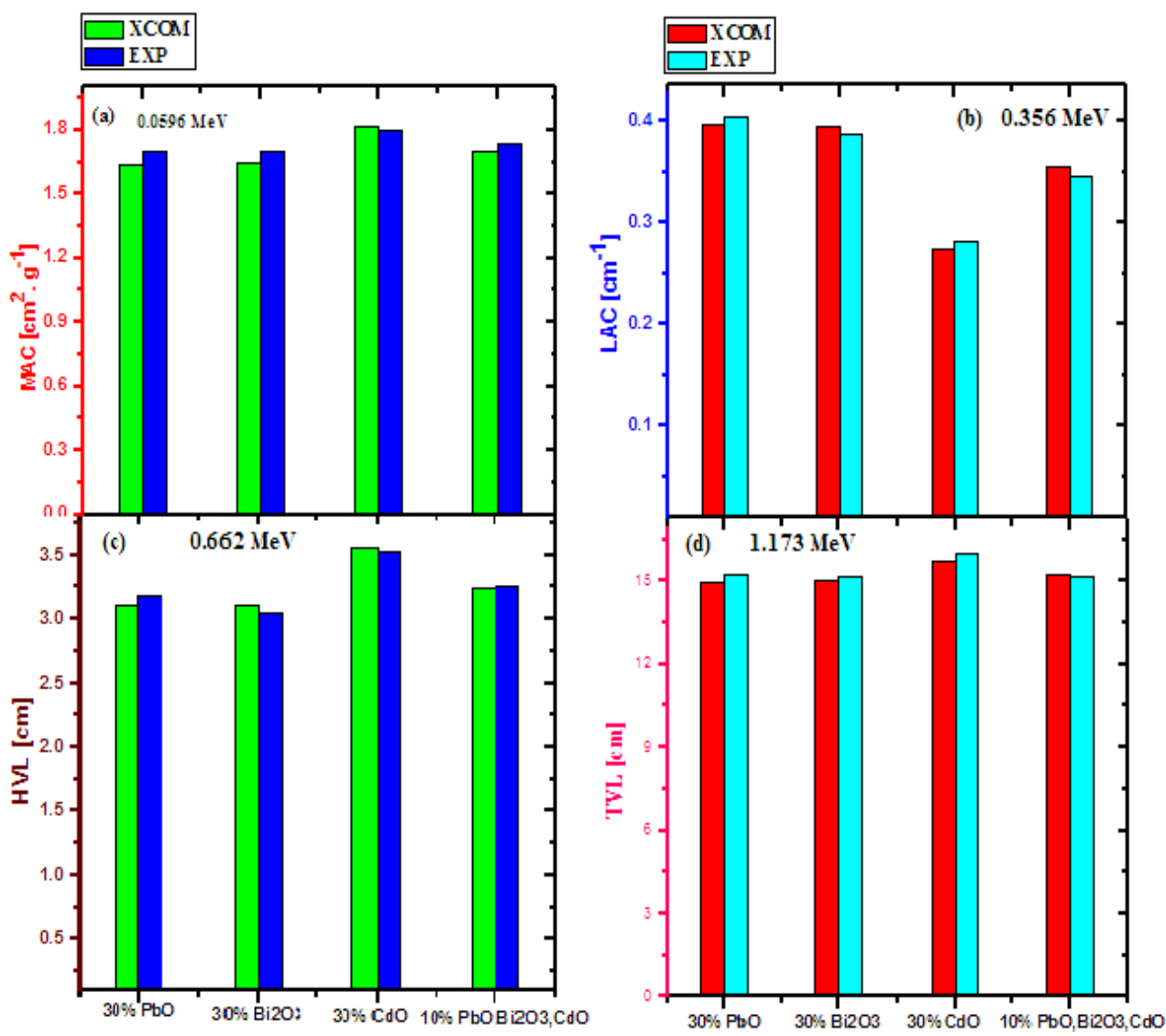

Figure 4. The difference between the experimental and XCOM results of (a) MAC at $0.0596 \mathrm{MeV}$, (b) LAC at $0.356 \mathrm{MeV}$, (c) HVL at $0.662 \mathrm{MeV}$ and (d) TVL at $1.173 \mathrm{MeV}$ for different $30 \%$ wt doped oxide-clays.

The effective atomic number $\left(Z_{\text {eff }}\right)$ of pure red clay, and red clay with $10 \mathrm{wt} \% \mathrm{PbO}$, $\mathrm{Bi}_{2} \mathrm{O}_{3}$ and $\mathrm{CdO}$ is illustrated in Figure $5 \mathrm{a}$, while Figure $5 \mathrm{~b}$ shows the results for red clay with $30 \mathrm{wt} \% \mathrm{PbO}, \mathrm{Bi}_{2} \mathrm{O}_{3}$, and $\mathrm{CdO}$, as well as for a red clay sample with $10 \mathrm{wt} \%$ of $\mathrm{PbO}$, $\mathrm{Bi}_{2} \mathrm{O}_{3}$, and $\mathrm{CdO}$ (totaling $30 \mathrm{wt} \%$ metal oxide). Figure $5 \mathrm{a}$ demonstrates that pure red clay has the lowest $Z_{\text {eff }}$ out of the tested samples, which means that introducing any of these three oxides into the clay will greatly enhance its $Z_{\text {eff, }}$, and, consequently, its attenuation capability. In addition, the figure shows that the $Z_{\text {eff }}$ for red clay with $10 \mathrm{wt} \% \mathrm{CdO}$ is lower than the $Z_{\text {eff }}$ of red clay with $10 \mathrm{wt} \% \mathrm{Bi}_{2} \mathrm{O}$ and $\mathrm{PbO}$, which is expected as $\mathrm{Cd}$ has a lower atomic number than $\mathrm{Bi}$ and $\mathrm{Pb}$. Meanwhile, pure red clay has a $Z_{\text {eff }}$ value of about 10-15, 15 at the lowest tested energy and then smoothly decreasing down to a constant value. The first subfigure also revealed a peak for the $\mathrm{CdO}$ clay and two peaks for both the $\mathrm{PbO}$ and $\mathrm{Bi}_{2} \mathrm{O}_{3}$ clays. These peaks can be attributed to the k-absorption edges of $\mathrm{Cd}, \mathrm{Pb}$, and $\mathrm{Bi}$. In Figure $5 \mathrm{~b}$, the $Z_{\text {eff }}$ for red clay with $30 \mathrm{wt} \% \mathrm{CdO}$ is once again lower than the $Z_{\text {eff }}$ of the clays with $30 \mathrm{wt} \% \mathrm{PbO}$ and $\mathrm{Bi}_{2} \mathrm{O}_{3}$, as well as the clay with $10 \mathrm{wt} \% \mathrm{CdO}, 10 \mathrm{wt} \% \mathrm{PbO}$, and $10 \mathrm{wt} \% \mathrm{Bi}_{2} \mathrm{O}_{3}$. One peak was observed for the red clay with $30 \mathrm{wt} \% \mathrm{CdO}$ and two peaks for the other samples, which confirms the conclusion that these peaks occur because of the presence of $\mathrm{Pb}$ and $\mathrm{Bi}$. In both figures it can be seen that the maximum $\mathrm{Z}_{\text {eff }}$ occurs 
at the lowest tested energy, and that the minimum values occur in the moderate-energy range (which is due to the Compton scattering effect). When comparing the $Z_{\text {eff }}$ values for the clay sample with $10 \mathrm{wt} \% \mathrm{PbO}$ to the sample with $30 \mathrm{wt} \% \mathrm{PbO}$, it can be seen that $Z_{\text {eff }}$ increases with an increase in $\mathrm{PbO}$ content, meaning that the $Z_{\text {eff }}$ of the red clay with $30 \mathrm{wt} \%$ $\mathrm{PbO}$ is greater than that of the sample with $10 \mathrm{wt} \% \mathrm{PbO}$. Therefore, adding more $\mathrm{PbO}$ to the clay samples improves the shielding ability of the red clay. This same conclusion applies to increased amounts of both $\mathrm{CdO}$ and $\mathrm{Bi}_{2} \mathrm{O}_{3}$.
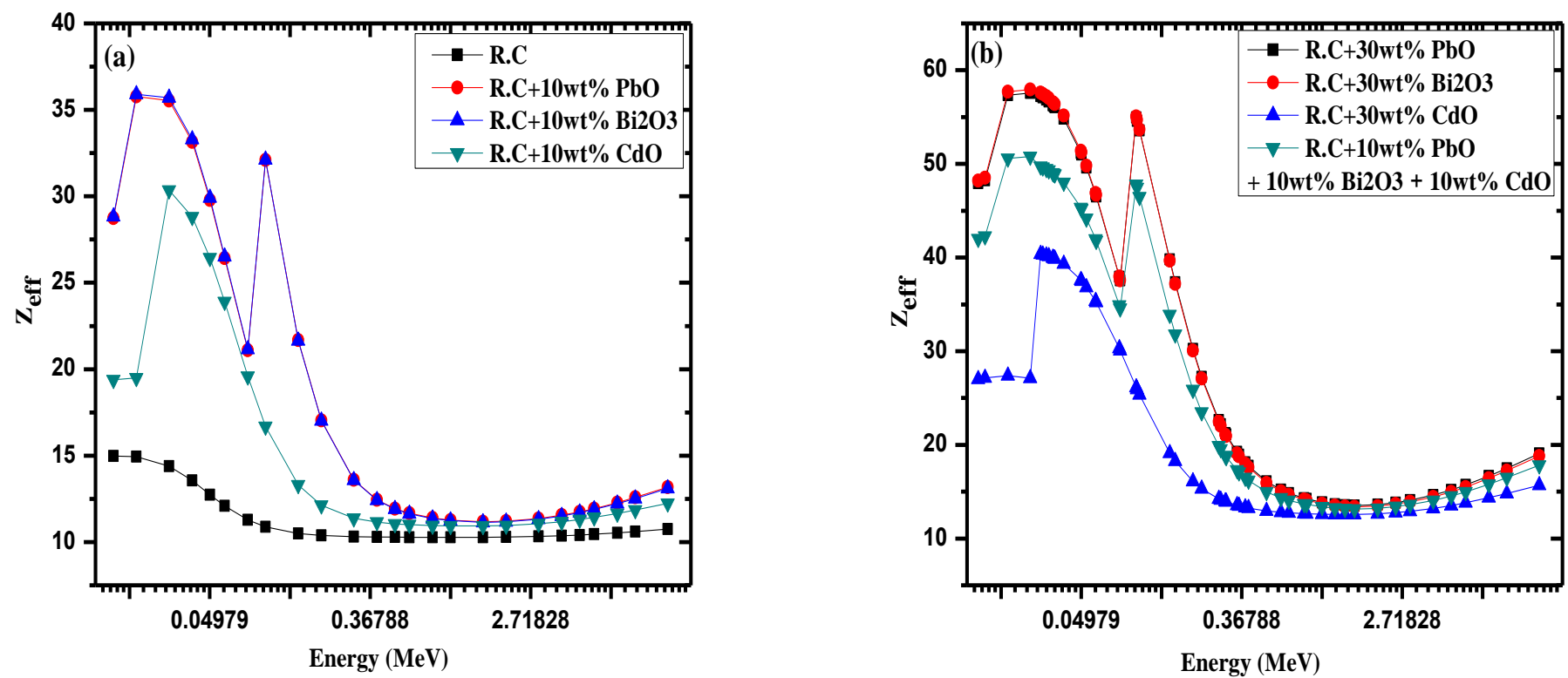

Figure 5. The effective atomic number as a function of energy, (a) $Z_{\text {eff }}$ of pure redl-clay as well as same the clay filled with $10 \%$ wt different oxides, and (b) $Z_{\text {eff }}$ of ball-clay filled with $30 \%$ wt different oxides.

The MAC for red clay with $10 \mathrm{wt} \% \mathrm{PbO}, \mathrm{Bi}_{2} \mathrm{O}_{3}$, and $\mathrm{CdO}$ microparticles were compared with the MAC of red clay with $10 \mathrm{wt} \% \mathrm{CdO}$ nanoparticles at four different energies (Figure 6a). This comparison tested the effect of decreasing particle size on the MAC of the red clays. The figure shows that the MAC of the red clay with $10 \mathrm{wt} \%$ nano-CdO was higher than the MAC of the clay containing microparticle samples. This difference is most evident at the lowest tested energy, and decreases as the energy increases. This result suggests that nanoparticles could be a useful way to enhance the shielding ability of current radiation-shielding materials.

Since the red clays containing nanoparticles outperformed the clays with microparticles, another red clay with $30 \mathrm{wt} \%$ nano-CdO was prepared, and the MAC for this sample was compared with that of the $30 \mathrm{wt} \%$ micro- $\mathrm{PbO}, \mathrm{Bi}_{2} \mathrm{O}_{3}$, and $\mathrm{CdO}$, as well as to that of a sample with $10 \mathrm{wt} \%$ micro- $\mathrm{PbO}, 10 \mathrm{wt} \%$ micro- $\mathrm{Bi}_{2} \mathrm{O}_{3}$, and $10 \% \mathrm{wt} \%$ micro-CdO. The results for these samples are graphed in Figure $6 \mathrm{~b}$. This figure shows that the MAC for the red clay with nano- $\mathrm{CdO}$ is higher than the $\mathrm{MAC}$ of the clay containing micro- $\mathrm{PbO}, \mathrm{CdO}$ and $\mathrm{Bi}_{2} \mathrm{O}_{3}$, which is especially apparent at the first tested energy. Therefore, it can be concluded that one method to improve the shielding ability of materials is to introduce nanoparticles rather than using microparticles. Additionally, it can be said that nano-CdO can be used as an alternative to $\mathrm{PbO}$ to create a more environmentally friendly shielding material. 

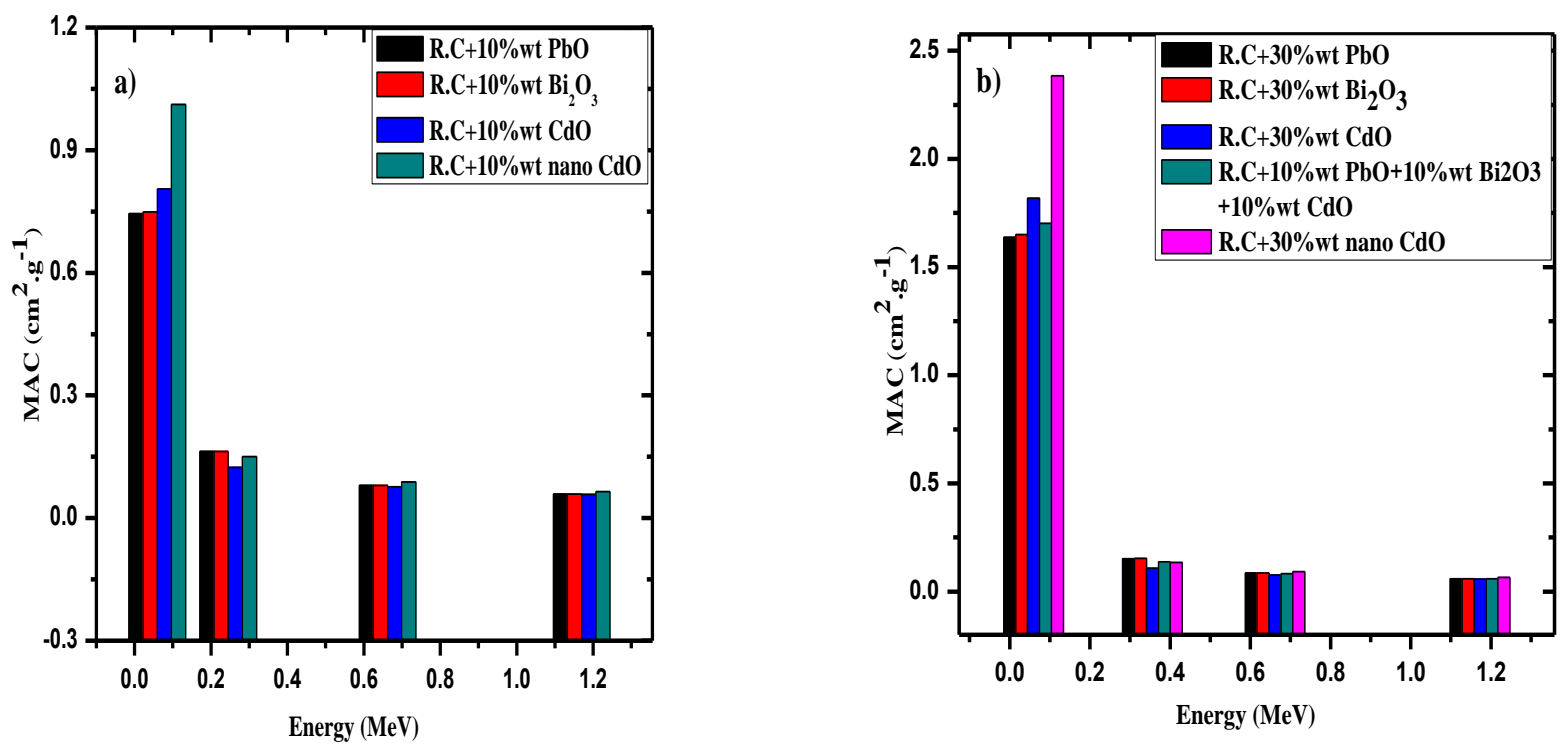

Figure 6. $(\mathbf{a}, \mathbf{b})$ The MAC for red clay filled with $10 \mathrm{wt} \%$ of different micro-oxides and $10 \mathrm{wt} \% \mathrm{CdO}$ nanoparticles.

Finally, the present ceramic samples based on red clay were compared with two other materials used as a shielding material in nuclear facilities (concrete [40], and white ceramic [41]) as shown in Figure 7, where the HVL values were 4.581; 4.582; 3.175; 3.049; $3.525 ; 3.526$; and $3.001(\mathrm{~cm})$ for concrete; white ceramic; R.C with $30 \mathrm{wt} \% \mathrm{PbO}$; R.C with $30 \mathrm{wt} \% \mathrm{Bi}_{2} \mathrm{O}_{3}$; R.C with $30 \mathrm{wt} \%$ bulk $\mathrm{CdO}$; R.C with $10 \mathrm{wt} \% \mathrm{PbO}, 10 \mathrm{wt} \% \mathrm{Bi}_{2} \mathrm{O}_{3}$ and $10 \mathrm{wt} \% \mathrm{CdO}$; and R.C with $30 \mathrm{wt} \%$ nano-CdO, respectively. The results indicated that the present ceramic-materials-based red clay has good radiation-shielding features.

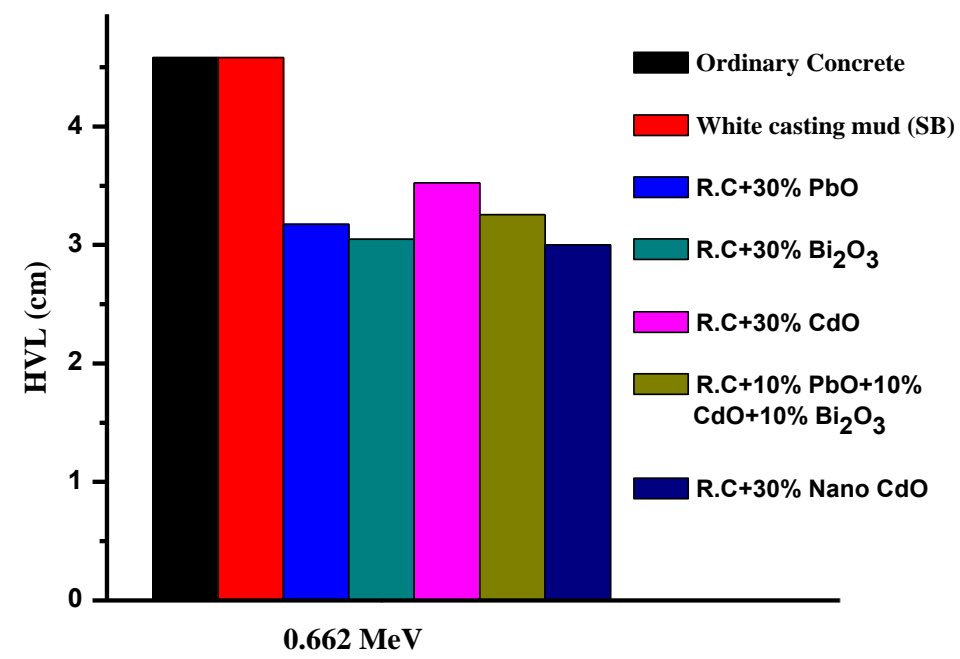

Figure 7. The HVL of the studied materials compared with ordinary concrete and white casting mud.

\section{Conclusions}

In summary, this work started by collecting red clays from Aswan city in Egypt and blending them with various percentages of three oxides $\left(\mathrm{PbO}, \mathrm{Bi}_{2} \mathrm{O}_{3}\right.$ and $\left.\mathrm{CdO}\right)$ with the aim of fabricating novel clay materials with enhanced gamma-radiation-shielding features. The MAC for the prepared materials was experimentally measured and compared with the theoretical results determined by XCOM. The measured and XCOM data agree to a very high degree of precision. Accordingly, the experimental setup used in this study can be reliably used to determine the shielding ability of the investigated clays. The $Z_{\text {eff }}$ of pure red clay, red clay with $10 \mathrm{wt} \%$, and red clay with $30 \mathrm{wt} \% \mathrm{PbO}, \mathrm{Bi}_{2} \mathrm{O}_{3}$, and $\mathrm{CdO}$ is reported. The $Z_{\text {eff }}$ results demonstrated that introducing any of these three oxides into 
clay will greatly enhance its $Z_{\text {eff, }}$, and, consequently, its attenuation capability. The $Z_{\text {eff }}$ for red clay with $30 \mathrm{wt} \% \mathrm{CdO}$ is lower than the $Z_{\text {eff }}$ of the clays with $30 \mathrm{wt} \% \mathrm{PbO}$ and $\mathrm{Bi}_{2} \mathrm{O}_{3}$, and the clay with $10 \mathrm{wt} \% \mathrm{CdO}, 10 \mathrm{wt} \% \mathrm{PbO}$, and $10 \mathrm{wt} \% \mathrm{Bi}_{2} \mathrm{O}_{3}$. Additionally, we found that the $Z_{\text {eff }}$ increases with an increase in $\mathrm{PbO}$ content, meaning that the $Z_{\text {eff }}$ of the red clay with $30 \mathrm{wt} \% \mathrm{PbO}$ is greater than that of the sample with $10 \mathrm{wt} \% \mathrm{PbO}$. We compared the MAC of red clay with nano-CdO, to that of red clay with micro- $\mathrm{PbO}$ and micro- $\mathrm{Bi}_{2} \mathrm{O}_{3}$, to understand the influence of particle size on the attenuation ability of the red clays. We found that the MAC for the red clay with nano-CdO was higher than the MAC of red clay wih micro- $\mathrm{PbO}, \mathrm{CdO}$, and $\mathrm{Bi}_{2} \mathrm{O}_{3}$. Therefore, it can be concluded that one method to improve the shielding ability of materials is to introduce nanoparticles rather than using microparticles. Additionally, it can be said that nano-CdO can be used as an alternative to $\mathrm{PbO}$ to create a more environmentally friendly shielding material.

Author Contributions: Conceptualization, M.E. and M.I.S.; methodology, M.F.D.; software, M.E., A.S.A.A. and A.A.; validation, M.I.S., M.I.A. and A.M.E.-K.; formal analysis, M.F.D.; investigation, M.E. and M.U.K.; resources, M.F.D.; data curation, A.M.E.-K.; writing-original draft preparation, M.F.D.; writing-review and editing, M.E. and M.I.S.; visualization, H.E.M.; supervision, M.I.A. and A.M.E.-K.; project administration, H.E.M. and A.S.A.A.; funding acquisition, M.F.D. All authors have read and agreed to the published version of the manuscript.

Funding: Taif Univeristy Researchers Supporting Project number (TURSP-2020/163), Taif 21944, Saudi Arabia.

Institutional Review Board Statement: Not applicable.

Informed Consent Statement: Not applicable.

Data Availability Statement: All data are available in the manuscript.mdpi.com/ethics. You might choose to exclude this statement if the study did not report any data.

Conflicts of Interest: The authors declare no conflict of interest.

\section{References}

1. Gencel, O.; Bozkurt, A.; Kam, E.; Yaras, A.; Erdogmus, E.; Sutcu, M. Gamma and neutron attenuation characteristics of bricks containing zinc extraction residue as a novel shielding material. Prog. Nucl. Energy 2021, 139, 103878. [CrossRef]

2. Tyagi, G.; Singhal, A.; Routroy, S.; Bhunia, D.; Lahoti, M. Radiation Shielding Concrete with alternate constituents: An approach to address multiple hazards. J. Hazard. Mater. 2021, 404, 124201. [CrossRef]

3. Reda, S.M.; Saleh, H.M. Calculation of the gamma radiation shielding efficiency of cement-bitumen portable container using MCNPX code. Prog. Nucl. Energy 2021, 142, 104012. [CrossRef]

4. Mahmoud, K.A.; Sayyed, M.I.; Tashlykov, O.L. Comparative studies between the shielding parameters of concretes with different additive aggregates using MCNP-5 simulation code. Radiat. Phys. Chem. 2019, 165, 108426. [CrossRef]

5. Sayyed, M.I.; Mhareb, M.H.A.; Alajerami, Y.S.M.; Mahmoud, K.A.; Imheidat, M.A.; Alshahri, F.; Alqahtani, M.; Al-Abdullah, T. Optical and radiation shielding features for a new series of borate glass samples. Optik 2021, 239, 166790. [CrossRef]

6. Sayyed, M.I.; Mohammed, F.Q.; Mahmoud, K.A.; Lacomme, E.; Kaky, K.M.; Khandaker, M.U.; Faruque, M.R.I. Evaluation of Radiation Shielding Features of Co and Ni-Based Superalloys Using MCNP-5 Code: Potential Use in Nuclear Safety. Appl. Sci. 2020, 10, 7680. [CrossRef]

7. Dong, M.; Xue, X.; Yang, H.; Li, Z. Highly cost-effective shielding composite made from vanadium slag and boron-rich slag and its properties. Radiat. Phys. Chem. 2017, 141, 239-244. [CrossRef]

8. Dong, M.; Xue, X.; Yang, H.; Liu, D.; Wang, C.; Li, Z. A novel comprehensive utilization of vanadium slag: As gamma ray shielding material. J. Hazard. Mater. 2016, 318, 751-757. [CrossRef]

9. Zoriyeh, H.; Erdem, S.; Gürbüz, E.; Bozbey, I. Nano-clay modified high plasticity soil as a building material: Micro-structure linked engineering properties and 3D digital crack analysis. J. Build. Eng. 2020, 27, 101005. [CrossRef]

10. Yaraş, A.; Sutcu, M.; Gencel, O.; Erdogmus, E. Use of carbonation sludge in clay based building materials processing for eco-friendly, lightweight and thermal insulation. Constr. Build. Mater. 2019, 224, 57-65. [CrossRef]

11. Ngo, D.C.; Saliba, J.; Saiyouri, N.; Sbartaï, Z.M. Design of a soil concrete as a new building material-Effect of clay and hemp proportions. J. Build. Eng. 2020, 32, 101553. [CrossRef]

12. Olukotun, S.F.; Gbenu, S.T.; Ibitoye, F.I.; Oladejo, O.F.; Shittu, H.O.; Fasasi, M.K.; Balogun, F.A. Investigation of gamma radiation shielding capability of two clay materials. Nucl. Eng. Technol. 2018, 50, 957-962. [CrossRef]

13. Akbulut, S.; Sehhatigdiri, A.; Eroglu, H.; Çelik, S. A research on the radiation shielding effects of clay, silica fume and cement samples. Radiat. Phys. Chem. 2015, 117, 88-92. [CrossRef] 
14. Mann, H.S.; Brar, G.S.; Mudahar, G.S. Gamma-ray shielding effectiveness of novel light-weight clay-flyash bricks. Radiat. Phys. Chem. 2016, 127, 97-101. [CrossRef]

15. Cheewasukhanont, W.; Limkitjaroenporn, P.; Kothan, S.; Kedkaew, C.; Kaewkhao, J. The effect of particle size on radiation shielding properties for bismuth borosilicate glass. Radiat. Phys. Chem. 2020, 172, 108791. [CrossRef]

16. Abunahel, B.M.; Ramli, R.M.; Quffa, K.M.; Azman, N.Z.N. Effect of nanofibrous porosity on the X-ray attenuation properties of electrospun n- $\mathrm{Bi}_{2} \mathrm{O}_{3}$ /epoxy-polyvinyl alcohol (PVA) nanofiber mats. Appl. Phys. A 2018, 124, 540. [CrossRef]

17. Azman, N.N.; Siddiqui, S.; Low, I. Characterisation of micro-sized and nano-sized tungsten oxide-epoxy composites for radiation shielding of diagnostic X-rays. Mater. Sci. Eng. C 2013, 33, 4952-4957. [CrossRef] [PubMed]

18. Abo-El-Enein, S.A.; El-Hosiny, F.I.; El-Gamal, S.M.A.; Amin, M.S.; Ramadan, M. Gamma radiation shielding, fire resistance and physicochemical characteristics of Portland cement pastes modified with synthesized $\mathrm{Fe}_{2} \mathrm{O}_{3}$ and $\mathrm{ZnO}$ nanoparticles. Constr. Build. Mater. 2018, 173, 687-706. [CrossRef]

19. Tiamduangtawan, P.; Kamkaew, C.; Kuntonwatchara, S.; Wimolmala, E.; Saenboonruang, K. Comparative mechanical, self-healing, and gamma attenuation properties of PVA hydrogels containing either nano- or micro-sized Bi2O3 for use as gamma-shielding materials. Radiat. Phys. Chem. 2020, 177, 109164. [CrossRef]

20. Verdipoor, K.; Alemi, A.; Mesbahi, A. Photon mass attenuation coefficients of a silicon resin loaded with $\mathrm{WO} 3, \mathrm{PbO}$, and $\mathrm{Bi} 2 \mathrm{O} 3$ Micro and Nano-particles for radiation shielding. Radiat. Phys. Chem. 2018, 147, 85-90. [CrossRef]

21. Tajudin, S.M.; Sabri, A.H.A.; Abdul Aziz, M.Z.; Olukotun, S.F.; Ojo, B.M.; Fasasi, M.K. Feasibility of clay-shielding material for low-energy photons (Gamma/X). Nucl. Eng. Technol. 2019, 51, 1633-1637. [CrossRef]

22. Baioumy, H.M.; Ismael, I.S. Composition, origin and industrial suitability of the Aswan ball clays, Egypt. Appl. Clay Sci. 2014, 102, 202-212. [CrossRef]

23. Xie, Y.; Zhang, B.; Liu, B.; Zeng, Z.; Zhang, Y.; Zheng, Y. Shrinkage cracking and strength deterioration of red clay under cyclic drying and wetting. Alex. Eng. J. 2021, 61, 2574-2588. [CrossRef]

24. Elsafi, M.; Alrashedi, M.F.; Sayyed, M.I.; Al-Hamarneh, I.F.; El-Nahal, M.A.; El-Khatib, M.; Khandaker, M.U.; Osman, H.; Askary, A.E. The Potentials of Egyptian and Indian Granites for Protection of Ionizing Radiation. Materials 2021, 14, 3928. [CrossRef] [PubMed]

25. Elsafi, M.; El-Nahal, M.A.; Alrashedi, M.F.; Olarinoye, O.I.; Sayyed, M.I.; Khandaker, M.U.; Osman, H.; Alamri, S.; Abbas, M.I. Shielding Properties of Some Marble Types: A Comprehensive Study of Experimental and XCOM Results. Materials 2021, 14, 4194. [CrossRef]

26. Sayyed, M.I.; Albarzan, B.; Almuqrin, A.H.; El-Khatib, A.M.; Kumar, A.; Tishkevich, D.I.; Trukhanov, A.V.; Elsafi, M. Experimental and Theoretical Study of Radiation Shielding Features of CaO- $\mathrm{K}_{2} \mathrm{O}-\mathrm{Na}_{2} \mathrm{O}-\mathrm{P}_{2} \mathrm{O}_{5}$ Glass Systems. Materials 2021, 14, 3772. [CrossRef] [PubMed]

27. Ibrahim, A.M.; Mohamed, A.R.; El-Khatib, A.M.; Alabsy, M.T.; Elsalamawy, M. Effect of hematite and iron slag as aggregate replacement on thermal, mechanical, and gamma-radiation shielding properties of concrete. Constr. Build. Mater. 2021, 310, 125225. [CrossRef]

28. Eid, M.S.; Bondouk, I.I.; Saleh, H.M.; Omar, K.M.; Sayyed, M.I.; El-Khatib, A.M.; Elsafi, M. Implementation of waste silicate glass into composition of ordinary cement for radiation shielding applications. Nucl. Eng. Technol. 2021, in press. [CrossRef]

29. Abbas, M.I. A new analytical method to calibrate cylindrical phoswich and $\mathrm{LaBr}_{3}(\mathrm{Ce})$ scintillation detectors. Nucl. Instrum. Methods Phys. Res. Sect. A Accel. Spectrometers Detect. Assoc. Equip. 2010, 621, 413-418. [CrossRef]

30. El-Khatib, A.M.; Salem, B.A.; Badawi, M.S.; Gouda, M.M.; Thabet, A.A.; Abbas, M.I. Full-Energy peak efficiency of an NaI(Tl) detector with coincidence summing correction showing the effect of the source-to-detector distance. Chin. J. Phys. 2017, 55, 478-489. [CrossRef]

31. Alabsy, M.T.; Alzahrani, J.S.; Sayyed, M.I.; Abbas, M.I.; Tishkevich, D.I.; El-Khatib, A.M.; Elsafi, M. Gamma-Ray Attenuation and Exposure Buildup Factor of Novel Polymers in Shielding Using Geant4 Simulation. Materials 2021, 14, 5051. [CrossRef]

32. Abbas, M.I. Validation of analytical formulae for the efficiency calibration of gamma detectors used in laboratory and in-situ measurements. Appl. Radiat. Isot. 2006, 64, 1661-1664. [CrossRef]

33. El-Khatib, A.M.; Elsafi, M.; Almutiri, M.N.; Mahmoud, R.M.M.; Alzahrani, J.S.; Sayyed, M.I.; Abbas, M.I. Enhancement of Bentonite Materials with Cement for Gamma-Ray Shielding Capability. Materials 2021, 14, 4697. [CrossRef] [PubMed]

34. Elsafi, M.; El-Nahal, M.A.; Sayyed, M.I.; Saleh, I.H.; Abbas, M.I. Effect of bulk and nanoparticle $\mathrm{Bi}_{2} \mathrm{O}_{3}$ on attenuation capability of radiation shielding glass. Ceram. Int. 2021, 47, 19651-19658. [CrossRef]

35. Al-Harbi, N.; Sayyed, M.I.; Al-Hadeethi, Y.; Kumar, A.; Elsafi, M.; Mahmoud, K.A.; Bradley, D.A. A novel CaO-K ${ }_{2} \mathrm{O}-\mathrm{Na}_{2} \mathrm{O}_{2} \mathrm{P}_{2} \mathrm{O}_{5}$ Glass Systems for Radiation Shielding Applications. Radiat. Phys. Chem. 2021, 188, 109645. [CrossRef]

36. Elsafi, M.; Sayyed, M.; Almuqrin, A.H.; Gouda, M.; El-Khatib, A. Analysis of particle size on mass dependent attenuation capability of bulk and nanoparticle $\mathrm{PbO}$ radiation shields. Results Phys. 2021, 26, 104458. [CrossRef]

37. Sayyed, M.I.; Olarinoye, O.I.; Elsafi, M. Assessment of gamma-radiation attenuation characteristics of $\mathrm{Bi}_{2} \mathrm{O}_{3}-\mathrm{B}_{2} \mathrm{O}_{3}-\mathrm{SiO}_{2}-\mathrm{Na}_{2} \mathrm{O}$ glasses using Geant4 simulation code. Eur. Phys. J. Plus 2021, 136, 104726. [CrossRef]

38. El-Nahal, M.A.; Elsafi, M.; Sayyed, M.I.; Khandaker, M.U.; Osman, H.; Elesawy, B.H.; Saleh, I.H.; Abbas, M.I. Understanding the Effect of Introducing Micro- and Nanoparticle Bismuth Oxide $\left(\mathrm{Bi}_{2} \mathrm{O}_{3}\right)$ on the Gamma Ray Shielding Performance of Novel Concrete. Materials 2021, 14, 6487. [CrossRef] [PubMed] 
39. Kaçal, M.R.; Akman, F.; Sayyed, M.I. Evaluation of gamma-ray and neutron attenuation properties of some polymers. Nucl. Eng. Technol. 2019, 51, 818-824. [CrossRef]

40. Bashter, I. Calculation of radiation attenuation coefficients for shielding concretes. Ann. Nucl. Energy 1997, $24,1389-1401$. [CrossRef]

41. Jawad, A.A.; Demirkol, N.; Gunoğlu, K.; Akkurt, I. Radiation shielding properties of some ceramic wasted samples. Int. J. Environ. Sci. Technol. 2019, 16, 5039-5042. [CrossRef] 